\title{
EFEKTIVITAS PROGRAM PEMULIHAN EKONOMI NASIONAL DALAM MENOPANG TINGKAT KESEJAHTERAAN MASYARAKAT KALIMANTAN SELATAN
}

\author{
Yenie Purnomoratih \\ Kanwil Ditjen Perbendaharaan Provinsi Kalimantan Selatan
}

\begin{abstract}
This article aims to analyze the effectiveness of National Economic Recovery program (Pemulihan Ekonomi Nasional/PEN) in supporting the level of walfare in South Kalimantan. In measuring the level of effectiveness, the indicators used are Gross Regional Domestic Product (GRDP) and the Open Unemployment Rate. The methods used in this article are the modelling of the exponential trend and the ARIMA time series forecasting. The measurement result shows that the PEN program that has been implemented in 2020 effectively supported the GRDP level of South Kalimantan better than the prognosis of the condition without the implementation of the PEN program. The PEN program also effectively holding back the rate of increase in the open unemployment rate in South Kalimantan to 4.74 percent, compared to the estimated condition without the implementation of the PEN program, which is 5.19 percent.
\end{abstract}

\begin{abstract}
Abstrak
Artikel ini bertujuan untuk menganalisis efektivitas program Pemulihan Ekonomi Nasional (PEN) dalam menopang tingkat kesejahteraan masyarakat di Kalimantan Selatan. Indikator yang digunakan dalam mengukur tingkat efektivitas program PEN adalah Produk Domestik Regional Bruto (PDRB) dan Tingkat Pengangguran Terbuka (TPT). Metode yang digunakan dalam artikel ini adalah pemodelan Trend Eksponensial dan Forecasting Deret Waktu ARIMA. Hasil pengukuran menunjukkan bahwa program PEN tahun 2020 secara efektif menopang tingkat kesejahteraan masyarakat Kalimantan Selatan sehingga mendorong tingkat PDRB Kalimantan Selatan jauh lebih baik dibandingkan dengan prognosis kondisi tanpa diimplementasikannya program PEN. Program PEN dapat menahan laju pertambahan angka pengangguran terbuka di Kalimantan Selatan menjadi 4,74 persen, dibandingkan perkiraan kondisi tanpa diimplementasikannya program PEN yaitu 5,19 persen.
\end{abstract}

Keywords: fiscal policy, pemulihan ekonomi nasional

JEL Classification: H30, H53, E27 


\section{PENDAHULUAN}

Organisasi Kesehatan Dunia (World Health Organization/WHO) pada awal Bulan Maret 2020 menyatakan Coronavirus Disease 2019 (COVID-19) sebagai pandemi. Merespon hal tersebut, Pemerintah Indonesia menetapkan Pembatasan Sosial Berskala Besar (PSBB) sebagai upaya memutus mata rantai penyebaran COVID-19. Tiongkok merupakan negara yang pertama memberlakukan lockdown, dan kemudian diikuti oleh Italia, Amerika Serikat, dan Korea Selatan yang melakukan penutupan seluruh maupun sebagian perbatasan negaranya serta membatasi pergerakan orang-orang untuk menekan penyebaran COVID-19. Studi yang dilakukan Asian Development Bank (ADB) dalam mengukur dampak COVID-19 terhadap perekonomian menyatakan bahwa COVID-19 diperkirakan berdampak pada penurunan Produk Dometik Bruto (PDB) global sebesar 6,4 persen hingga 9,7 persen, lebih besar dibandingkan perkiraan hasil studi yang dilakukan International Monetary Fund (IMF) yang menyebutkan COVID-19 diperkirakan berdampak terhadap menurunnya PDB global sebesar 6,3 persen (Park et al., 2020). Sebagaimana yang terjadi di negara-negara lain, PSBB juga menyebabkan lumpuhnya aktivitas ekonomi, dan akhirnya berdampak pada penurunan tingkat perekonomian Indonesia secara umum.

Data pertumbuhan ekonomi Indonesia di Triwulan I 2020 hanya berada di angka 2,97 persen, lebih rendah dari yang ditargetkan sebesar 3,5 persen sampai 4 persen. Pelemahan pertumbuhan yang tidak sesuai target tersebut terus terjadi hingga berturut- turut di Triwulan II sebesar minus 1,26 persen dan Triwulan III sebesar minus 2,03 persen. Kondisi yang sama juga terjadi di Kalimantan Selatan. Sebagai salah satu wilayah yang dinilai menjadi epicentrum penularan COVID-19 selain DKI Jakarta, Surabaya, dan Makasar oleh Satgas COVID-19, dampak pandemi COVID-19 terhadap pertumbuhan ekonomi Kalimantan Selatan juga menyebabkan pelemahan ekonomi hingga $-2,61$ persen di Triwulan II dan $-4,68$ persen di Triwulan III 2020.

Sektor manufaktur, perdagangan, pertambangan dan penggalian, serta konstruksi yang menjadi kontributor utama terhadap PDB, tercatat telah mengalami kontraksi. Pada saat yang sama, konsumsi rumah tangga yang selalu menjadi penopang PDB juga ikut turun akibat merosotnya daya beli masyarakat. Demikian juga yang terjadi di Kalimantan Selatan, bahwa tingkat konsumsi riil rumah tangga dan Lembaga Non-Profit yang melayani Rumah Tangga (LNPRT) nya terpuruk bahkan hingga minus 9,11 persen di Triwulan I 2020 dibandingkan dengan periode yang sama pada tahun 2019. Kondisi tersebut akan sangat berpengaruh pada tingkat penerimaan negara, yang kemudian ditambah dengan tuntutan dari para pelaku usaha yang meminta keringanan pajak.

Penurunan aktivitas perekonomian mengakibatkan target angka inflasi yang telah disepakati antara Pemerintah dan Dewan Perwakilan Rakyat (DPR) sebagaimana tertuang dalam Kerangka Ekonomi Makro menjadi tidak tercapai. Padahal target inflasi dimaksudkan untuk memicu masyarakat untuk melakukan aktivitas perekonomian. Kondisi tersebut pada 
gilirannya menyebabkan bertambahnya tingkat pengangguran di masyarakat. Data mencatat tingkat pengangguran terbuka di Indonesia meningkat dari 4,99 persen di Bulan Februari menjadi 7,07 persen di Bulan Agustus 2020. Demikian pula yang terjadi di Kalimantan Selatan, tingkat pengangguran terbuka meningkat dari 3,80 persen di Bulan Februari menjadi 4,74 persen di Bulan Agustus 2020. Serupa dengan kondisi yang terjadi pada masa pandemic MERS, SARS, Ebola dll, hal terpenting yang dibutuhkan adalah memahami dampak dan kemudian menetapkan kebijakan untuk memitigasi dampak tersebut (Pike et al., 2014 \& Busch et al., 2015, dalam Stephens, 2017). Lebih lanjut terkait penanganan dampak pandemi, bahwa dalam memahami ilmu ekonomi sebuah pandemi dapat dilakukan melalui kebijakan untuk mengurangi dampak negatif terhadap ekonomi; sebagaimana dalam kasus SARS, yang dampak ekonominya jauh melebihi dari penyakit menular itu sendiri (Lee et al., 2003, dalam Stephens, 2017).

Menghadapi itu, peran Pemerintah sangat dibutuhkan. Bulan Maret 2020, Pemerintah memutuskan meluncurkan program Pemulihan Ekonomi Nasional (PEN). Berdasarkan Peraturan Pemerintah Nomor 23 Tahun 2020, secara prinsip program PEN ditujukan untuk melindungi, mempertahankan, dan meningkatkan kemampuan ekonomi. Program PEN dimaksudkan sebagai langkah cepat pemerintah Indonesia untuk mengatasi kondisi perekonomian dari kejatuhan yang semakin dalam. Oleh karena itu, tulisan ini disusun sebagai kajian untuk mengukur efektivitas program PEN. Ukuran efektivitas dilihat dari dampaknya terhadap tingkat kesejahteraan, dengan menggunakan Produk Domestik Regional Bruto (PDRB) dan Tingkat Pengangguran Terbuka (TPT) di Kalimantan Selatan sebagai data proksi. Dalam hal ini, Kalimantan Selatan merupakan salah satu daerah epicentrum penularan COVID-19 di Indonesia sebagaimana penilaian Satgas COVID-19 Indonesia (Putri, 2020). Kondisi tersebut sangat memungkinkan adanya dampak yang lebih besar dibandingkan daerah yang bukan epicentrum.

\section{TINJAUAN LITERATUR}

Menurut Abiad et al. (2020), kondisi ekonomi yang terjadi di masa pandemi di antaranya berupa penurunan konsumsi domestik, penurunan di sektor pariwisata dan bisnis perjalanan, disrupsi kegiatan perdagangan dan produksi, serta pergeseran fokus belanja yang diarahkan untuk perawatan kesehatan. Intervensi yang diperlukan untuk menghadapi ancaman yang membahayakan perekonomian dapat dilakukan melalui penguatan tingkat konsumsi domestik maupun fokus belanja, mengigat 2 (dua) hal tersebut merupakan komponen penopang dalam pembentukan tingkat perekonomian (Produk Domestik Regional Bruto/PDRB). Dalam konteks kajian ini, intervensi Pemerintah melalui program PEN untuk penguatan tingkat konsumsi masyarakat dan fokus belanja Pemerintah akan diukur pengaruhnya terhadap PDRB sebagai proksi dalam menilai tingkat perekonomian di Kalimantan Selatan.

Evaluasi terhadap kesejahteraan masyarakat dalam menghadapi dampak krisis pandemi dilakukan dari berbagai 
strategi harus mempertimbangkan kondisi kesehatan masyarakat bersamaan dengan kondisi ekonominya (Chang and Velasco, 2020a., World Bank 2020f, dalam Loayza, 2020). Di Indonesia, indikator yang digunakan oleh Badan Pusat Statistik (BPS) untuk memudahkan intepretasi dalam mengukur taraf kesejahteraan, di antaranya menggunakan pendekatan ketenagakerjaan, tingkat dan pola konsumsi masyarakat, kesehatan, pendidikan, kemiskinan, serta aspek sosial lainnya.

\section{METODOLOGI PENELITIAN}

Kajian efektivitas program PEN di Provinsi Kalimantan Selatan ini menggunakan metode deskriptif kuantitatif. Penelitian yang dilakukan adalah penelitian sekunder (desk research), dengan menggunakan data sekunder yang bersumber dari BPS dan hasil Kajian Fiskal Regional Provinsi Kalimantan Selatan Triwulan I s.d. III, dan tahunan 2020. Dalam mengukur tingkat efektfitas program PEN di Kalimantan Selatan dalam kajian ini, indikator yang digunakan adalah Produk Domestik Regional Bruto (PDRB) dan Tingkat Pengangguran Terbuka (TPT). Data PDRB dan TPT yang digunakan merupakan data yang dirilis oleh BPS Kalimantan Selatan.

Model tren eksponensial digunakan untuk mengukur prognosis komponen tingkat konsumsi masyarakat (C). Model forecasting deret waktu ARIMA digunakan untuk mengukur prognosis belanja pemerintah (G) dan prognosis Tingkat Pengangguran Terbuka (TPT). Data prognosis tingkat konsumsi masyarakat (C) bersama dengan data prognosis belanja pemerintah

(G) dioperasionalkan dalam mengukur prognosis PDRB. Data prognosis tingkat PDRB dan TPT menjadi proksi untuk mengukur tingkat kesejahteraan masyarakat dalam kondisi tanpa diimplementasikannya program PEN, yang kemudian dikomparasikan dengan PDRB dan TPT eksisting setelah diimplementasikannya program PEN.

\section{HASIL PENELITIAN DAN PEMBAHASAN \\ Profil Program PEN di Provinsi Kalimantan Selatan}

Program PEN merupakan langkah strategis yang ditempuh oleh Pemerintah. Diawali dengan penetapan Peraturan Pemerintah Pengganti Undang-Undang (PERPPU) Nomor 1 Tahun 2020 tentang Kebijakan Keuangan Negara dan Stabilitas Sistem Keuangan untuk Penanganan Pandemi COVID-19 dan/atau Dalam Rangka Menghadapi Ancaman Yang Membahayakan Perekonomian Nasional dan/atau Stabilitas Sistem Keuangan. Selanjutnya sebagai bagian dari pengimplementasian ketentuan tersebut, program PEN mulai dijalankan melalui penetapan Peraturan Pemerintah Nomor 23 Tahun 2020 tentang Pelaksanaan Program Pemulihan Ekonomi Nasional Untuk Mendukung Kebijakan Keuangan Negara Untuk Penanganan Pandemi Corona Virus Disease 2019 (COVID-19) Dan/Atau Untuk Menghadapi Ancaman Yang Membahayakan Perekonomian Nasional dan/atau Stabilitas Sistem Keuangan Serta Penyelamatan Ekonomi Nasional (PEN). Pelaksanaan program PEN dimulai sejak bulan Maret, yang diawali dengan pembayaran tunjangan kepada para tenaga Kesehatan dan 
kemudian diikuti dengan beragam program bantuan yang dikelompokkan dalam beberapa klaster. Alokasi belanja penanganan COVID-19 seperti santunan kematian, klaim Rumah Sakit, maupun insentif bagi tenaga Kesehatan dalam sektor/klaster Kesehatan merupakan bagian yang tidak terpisahkan dari rangkaian kegiatan pemulihan perekonomian Nasional sebagaimana tertuang dalam Peraturan Pemerintah Nomor 23 Tahun 2020 yang diubah dengan Peraturan Pemerintah Nomor 43 Tahun 2020.

Jumlah alokasi anggaran untuk masing-masing klaster dalam APBN ditetapkan dengan Peraturan Presiden (Perpres) Nomor 72 Tahun 2020 tentang Perubahan Atas Peraturan Presiden Nomor 4 Tahun 2020 tentang Perubahan Postur dan Rincian APBN Tahun Anggaran 2020. Berdasarkan Peraturan Menteri Keuangan Nomor 185/PMK.02/2020 tentang Pengelolaan Anggaran Dalam Rangka Penanganan Pandemi COVID-19 dan/atau Program Pemulihan Ekonomi Nasional, program penanganan pandemic COVID-19 dan/atau program PEN meliputi sektorsektor sebagai berikut.

\section{Sektor Kesehatan}

Anggaran belanja sektor kesehatan ini merupakan anggaran belanja penanganan dampak COVID-19 yang sifatnya langsung. Sebagaimana dinyatakan di atas, bahwa evaluasi ataupun pengukuran terhadap kesejahteraan masyarakat dalam menghadapi dampak krisis pandemi dilakukan dari berbagai strategi harus mempertimbangkan kondisi kesehatan masyarakat bersamaan dengan kondisi ekonominya. Oleh karenanya, penanganan kesehatan akibat COVID-
19 termasuk menjadi bagian dari program pemulihan ekonomi. Adapun total anggaran belanja yang dialokasikan dalam klaster Kesehatan adalah sebesar 97,260 triliun rupiah. Jenis program yang dilaksanakan dalam struktur klaster kesehatan ini meliputi beberapa jenis insentif, yaitu: 1) Belanja Penanganan COVID-19 lainnya; 2) Insentif Tenaga Medis; 3) Santunan Tenaga Medis; 4) Bantuan Iuran JKN; 5) Gugus Tugas COVID-19; 6) Cadangan Penanganan Vaksin; 7) Cadangan Vaksin perlindungan sosial Tahun 2021.

Sebagian besar alokasi anggaran pada klaster Kesehatan ini baru direalisasikan pada akhir Triwulan ke-2 dan awal Triwulan ke-3, kecuali bantuan atau insentif dan santunan kepada Tenaga Kesehatan pusat yang sudah terealisasi sejak Bulan Maret 2020. Untuk Kalimantan Selatan, realisasi klaster Kesehatan pada tahun 2020 adalah sebesar 25,24 miliar rupiah yang diberikan kepada 3.250 orang tenaga Kesehatan dan sebesar 7,93 miliar rupiah untuk bantuan klaim penggantian biaya perawatan pasien COVID-19.

\section{Sektor Perlindungan Sosial}

Klaster ini merupakan kelompok yang memiliki pagu alokasi anggaran terbesar dalam program PEN secara keseluruhan. Dalam klaster ini, beberapa program perlindungan sosial yang dijalankan oleh Pemerintah meliputi bantuan sosial: 1) Program Keluarga Harapan (PKH); 2) Bantuan Pemerintah Non Tunai (BPNT) sembako; 3) sembako Jabodetabek; 4) Bantuan Sosial Tunai non Jabodetabek; 5) Kartu Prakerja; 6) diskon listrik; 7) Bantuan Langsung Tunai (BLT) Dana Desa; 8) Subsidi gaji/upah; 9) subsidi kuota 
internet; 10) bantuan internet dan bantuan tunai guru; 11) Bantuan gaji honorer guru. Berdasarkan jenis program bantuan sosial yang diberikan, beberapa jenis program yang dijalankan tersebut merupakan program reguler yang kemudian dilakukan perluasan untuk menjaga daya beli masyarakat, dalam kerangka konsumsi nasional sebagai pengungkit pertumbuhan ekonomi.

Kinerja kealisasi klaster Perlindungan Sosial pada tahun 2020 di Provinsi Kalimantan Selatan mencapai 2.253,2 miliar rupiah. Secara detail realisasi anggaran untuk programprogram dukungan fiskal pemerintah di Kalimantan Selatan, masing-masing sebesar: 1) Program $\mathrm{PKH}$ terealisasi sebesar 343,16 miliar rupiah yang diterima oleh 845.529 keluarga penerima manfaat; 2) BPNT sembako terealisasi sebesar 419,16 miliar rupiah yang diterima oleh 2.171.228 Keluarga Penerima Manfaat; 3) Bantuan Sosial Tunai terealisasi sebesar 273,31 miliar rupiah; 4) Bantuan Sosial beras kepada KPM PKH terealisasi 4.293.945 kg diterimakan kepada 95.421 Keluarga Penerima Manfaat; 5) bantuan Kartu Prakerja terealisasi sebesar 467,93 miliar rupiah yang diterima oleh 131.811 peserta; 6) Bantuan Subsidi Upah telah terealisasi 461,19 miliar rupiah yang diberikan kepada 384.326 penerima subsidi; 7) Diskon Tarif Listrik Rumah Tangga dan UMKM telah tersalur sebesar 288,46 miliar rupiah yang diberikan kepada 565.442 pelanggan dari segmen Rumah Tangga pengguna daya 450 VA, kepada 123.431 pelanggan dari segmen Rumah Tangga pengguna daya 900 VA, serta kepada 15.518 pelanggan dari segmen bisnis UMKM pengguna daya $450 \mathrm{VA}$.

\section{Sektor Dukungan Sektoral Kementerian/Lembaga (K/L) dan Pemerintah Daerah}

Berdasarkan Perpres 72 Tahun 2020, jumlah anggaran untuk program PEN yang dialokasikan melalui anggaran K/L dan Pemda adalah sebesar 65.970 miliar rupiah. Dalam klaster sektoral K/L dan Pemerintahan Daerah (PEMDA), dukungan fiskal Pemerintah diberikan berupa: 1) program Padat Karya yang terdapat dalam alokasi anggaran Kementerian Pertanian, Kementerian Perhubungan, Kementerian Kelautan Perikanan, dan Kementerian PUPR; 2) insentif perumahan yang meliputi subsidi bunga kredit perumahan dan subsidi bantuan uang muka perumahan; 3) dukungan pariwisata yang diberikan kepada Pemda, subsidi pelayanan jasa penumpang pesawat udara, dan subsidi biaya kalibrasi fasilitas penerbangan; 4) Dana Insentif Daerah pemulihan ekonomi; 5) cadangan Dana Alokasi Khusus (DAK) fisik; 6) fasilitas pinjaman daerah

Pada Kementerian Pertanian, alokasi anggaran program PEN secara nasional adalah sebesar 1.219,6 miliar rupiah, sedangkan yang dialokasikan untuk disalurkan di Provinsi Kalimantan Selatan pada tahun 2020 sebesar 57,16 miliar rupiah, dengan kinerja realisasinya mencapai 49,51 miliar rupiah. Realisasi tersebut telah diterima oleh 95.426 tenaga kerja di sektor pertanian yang ada di lingkup Provinsi Kalimantan Selatan.

Anggaran program PEN yang teralokasi di Kementerian Perhubungan untuk Kalimantan Selatan, alokasi yang disediakan pada tahun 2020 adalah sebesar 26,71 miliar rupiah, dengan 
kinerja realisasi mencapai 23,72 miliar rupiah.

Alokasi anggaran program PEN yang terdapat dalam struktur anggaran Kementerian PUPR yang disalurkan di Provinsi Kalimantan Selatan pada tahun 2020 adalah sebesar 176,17 juta rupiah, dengan realisasi sebesar 173,85 juta rupiah yang diterimakan kepada 15.990 orang pekerja.

Dalam alokasi Kementerian Lingkungan Hidup dan Kehutanan, yang di salurkan di Kalimantan Selatan pada tahun 2020 adalah sebesar 53,83 miliar rupiah, dengan realisasi penyaluran sebesar 40,93 miliar rupiah dan capaian realisasi output sebesar 11.864 ha.

Sementara untuk pelaksanaan program PEN di Pemerintahan Daerah (PEMDA), anggaran program PEN diberikan dalam beberapa dukungan fiskal.

\section{Pemberian Bantuan Operasional Kesehatan (BOK) tambahan.} Sebagaimana bantuan yang diberikan kepada tenaga Kesehatan Pusat, insentif bagi tenaga kesehatan Daerah diberikan sebagai wujud penghargaan atas perjuangan para tenaga Kesehatan dalam menangani COVID-19. Mekanisme pengalokasian anggaran insentif ini dilakukan melalui tambahan dana BOK. Keseluruhan alokasi dukungan fiskal untuk BOK tambahan adalah sebesar 3,7 triliun rupiah.

Cadangan Dana Alokasi Khusus (DAK)fisik. Dukungan fiskal ini diberikan untuk memulihkan perekonomian di Daerah, dengan memulihkan Kembali Sebagian alokasi DAK Fisik yang sempat dihentikan. DAK Fisik yang dipulihkan adalah yang bersifat melibatkan stakeholder lokal, penyedia atau pengembang lokal, yang menggunakan material lokal dan banyak menyerap tenaga kerja lokal, serta merupakan pekerjaan fisik yang selesai dalam waktu 5 bulan. Di Kalimantan Selatan pada tahun 2020 telah tersalur sebesar 208,49 miliar rupiah.

Dana Insentif Daerah tambahan. Alokasi fiskal ini diberikan sebagai motivasi dan insentif kepada Daerah atas tatanan normal baru kepada Pemda yang: mengurangi jumlah paparan COVID-19 secara Nasional, berhasil melakukan pencegahan dan penanggulangan COVID-19 secara efektif berdasarkan zonasi yang ditentukan oleh Badan Nasional Penanggulangan Bencana (BNPB), mendukung percepatan pemulihan ekonomi Daerah, serta mendorong inovasi untuk penerapan protokol COVID-19. Dari alokasi 5 triliun rupiah yang disediakan, tersalurkan sebesar 4.910,25 miliar rupiah atau 98,2 persen untuk total sebanyak 419 Daerah.

Bantuan Langsung Tunai (BLT) Desa. Bantuan fiskal dari Pemerintah ini diberikan kepada keluarga miskin di Desa yang tidak termasuk penrima Program Keluarga Harapan, Kartu Sembako, dan Kartu Prakerja. Alokasi yang disediakan oleh Pemerintah untuk Kalimantan Selatan pada tahun 2020 telah tersalur 387,88 miliar rupiah untuk 1.864 desa.

\section{Sektor Dukungan kepada Usaha Mikro, Kecil, dan Menengah (UMKM)} Pada tahun 2020, program PEN dalam kelompok perlindungan usaha ini telah disalurkan kepada 163.326 pelaku usaha mikro di Provinsi Kalimantan Selatan, yang masingmasingnya menerima sebesar 2,4 juta rupiah. Berdasarkan Perpres 72 Tahun 2020, dukungan fiskal pemerintah bagi 
para pelaku UMKM di Indonesia pada tahun 2020 adalah sebesar 28.800 miliar rupiah, yang telah tersalurkan seluruhnya kepada 12 juta orang pelaku UMKM.

\section{Sektor Insentif Usaha}

Program PEN juga dijalankan Pemerintah sebagai respon terhadap tingginya tekanan akibat makin meluasnya dampak pandemi COVID-19 terhadap banyak kegiatan perekonomian. Untuk itu, Pemerintah telah memberikan beberapa insentif berupa keringanan pajak selama masa pandemi.

Sejak April Tahun 2020, terdapat beberapa fasilitas kemudahan atau keringanan yang diberikan pemerintah kepada berbagai sektor usaha. Diawali dengan penetapan Peraturan Menteri Keuangan Nomor 28/PMK.03/2020 tentang Pemberian Fasilitas Pajak Terhadap Barang dan Jasa Yang Diperlukan Dalam Rangka Penanganan Pandemi COVID-19. Kebijakan tersebut kemudian diikuti dengan kebijakan perluasan cakupan Klasifikasi Lapangan Usaha sebagaimana yang ditetapkan dalam Peraturan Menteri Keuangan Nomor 44/PMK.03/2020 tentang Insentif Pajak Untuk Wajib Pajak Terdampak Pandemi COVID-19. Ragam jenis keringanan dan fasilitas yang diberikan di Kalimantan Selatan dalam rangka menanggulangi dampak pandemi dan pemulihan ekonomi Nasional yang diberikan meliputi pajakpajak sebagai berikut (sumber: Kanwil Direktorat Jenderal Pajak Kalimantan Selatan dan Tengah, 2020).

\section{Pajak Penghasilan Pasal 21} Ditanggung Pemerintah. Insentif pajak ini atas penghasilan yang diterima wajib pajak orang pribadi dalam negeri sebagai imbalan yang diberikan oleh unit instansi pemerintah, rumah sakit, dan pihak lain yang ditunjuk atas jasa yang diperlukan dalam rangka penanganan Covid-19. Di regional Kalimantan Selatan dan Tengah, realisasi PPh pasal 21 yang ditanggung Pemerintah (DTP PPH pasal 21) sampai dengan akhir tahun 2020 adalah sebesar 61,45 miliar rupiah. Data tersebut merupakan laporan dari 1.010 Wajib Pajak di wilayah kerja Kanwil Ditjen Pajak Kalimantan Selatan dan Tengah.

Pajak Penghasilan Pasal 22 dan Pasal 22 Impor Ditanggung Pemerintah.

Diberikan terhadap impor dan perdagangan barang yang diperlukan dalam rangka penanganan pandemi Covid-19 yang dilakukan oleh instansi pemerintah, rumah sakit, dan pihak lain yang ditunjuk. Insentif pajak penghasilan Pasal 22 dan Pasal 22 Impor juga diberikan atas impor atau pembelian bahan baku untuk memproduksi vaksin atau obat untuk penanganan Covid-19 oleh industri farmasi produksi vaksin atau obat, serta atas penjualan barang yang dilakukan oleh pihak penjual yang bertransaksi dengan instansi pemerintah, rumah sakit, dan pihak yang ditunjuk. Hingga akhir tahun 2020, jumlah DTP PPh pasal 22 impor yang tercatat di Kalimantan Selatan adalah sebesar 1,51 miliar rupiah. Berdasarkan data Kanwil Ditjen Pajak Kalimantan Selatan dan Tengah, jumlah tersebut merupakan DTP PPh pasal 22 impor dari 6 (enam) importir Wajib Lapor, dari nilai impor sebesar 59,13 miliar rupiah.

Pajak Penghasilan Pasal 23 Ditanggung Pemerintah. Insentif yang diberikan atas penghasilan yang diterima wajib pajak badan dalam 
negeri dan bentuk usaha tetap sebagai imbalan yang diberikan oleh instansi pemerintah, rumah sakit, dan pihak lain atas jasa teknik, manajemen, atau jasa lain yang diperlukan dalam rangka penanganan wabah Covid-19. Di Kalimantan Selatan, jumlah realisasi PPh pasal 23 ditanggung pemerintah sampai dengan akhir tahun 2020 adalah sebesar 7,8 miliar rupiah. Insentif ini dimanfaatkan oleh 1.721 wajib lapor PPh pasal 23 yang ada di Kalimantan Selatan.

Pajak Penghasilan Pasal 25
Ditanggung Pemerintah. Fasilitas keringanan pajak yang diberikan kepada perusahaan atau pelaku usaha jasa konstruksi tertentu yang terdampak COVID-19. Terhadap pajak yang terutang, diberikan insentif pengurangan angsuran sebesar 50 persen. Di wilayah Kalimantan Selatan, insentif pengurangan angsuran $\mathrm{PPh}$ pasal 25 ini diberikan sebesar 173,59 miliar rupiah. Jumlah tersebut dinyatakan oleh Kanwil Ditjen Pajak Kalimantan Selatan dan Tengah berasal dari 612 Wajib Pajak dengan total PPh pasal 25 terutang sebesar 407,83 miliar rupiah.

Nilai pemberian insentif dan keringanan Pajak di skala Nasional sebesar 123,01 triliun rupiah. Diharapkan insentif tersebut dapat terserap dan dimanfaatkan oleh wajib pajak yang berhak (eligible). Berdasarkan PMK Nomor 44/PMK.03/2020, insentif PPh Pasal 21 ditanggung pemerintah (DTP) berlaku untuk 1.062 Klasifikasi Lapangan Usaha (KLU), pemberian insentif pembebasan dari pemungutan PPh Pasal 22 Impor untuk $431 \mathrm{KLU}$, insentif pengurangan PPh Pasal 25 diberikan untuk 846 KLU, dan insentif restitusi PPN dipercepat hingga jumlah lebih bayar maksimal 5 miliar rupiah pemberiannya ditujukan untuk 431 KLU.

Data di akhir Triwulan III menunjukkan bahwa Pendapatan Negara dan Hibah mencapai 1.158,99 triliun rupiah atau 68,18 persen dari target APBN pada Perpres 72/2020. Capaian Pendapatan Negara tersebut mengalami kontraksi 13,65 persen Year on Year (YoY).

Pada skala regional, realisasi Penerimaan Perpajakan Provinsi Kalimantan Selatan pun mengalami kontraksi. Di awal Triwulan IV 2020 kontraksi yang tercatat bahkan mencapai 19,48 persen secara YoY, yang banyak disumbang oleh penurunan kinerja sektor Pertambangan serta Perdagangan Besar dan Kecil sebagai sektor utama pendukung penerimaan perpajakan di Kalimantan Selatan (Gambar 1).

$\begin{array}{ccr}\text { Seiring } & \text { dengan } & \text { mulai } \\ \text { dimanfaatkannya } & \text { keringanan dan }\end{array}$
insentif Pajak, Pemerintah melalui Direktorat Jenderal Pajak melakukan penyesuaian target atas penerimaan perpajakan. Sebagaimana pengaturan dalam PMK Nomor 44/PMK.03/2020, penyesuaian target terbesar dilakukan terhadap target penerimaan PPh dan PPN. Besaran koreksi target penerimaan atas PPH di Kalimantan Selatan bahkan mencapai 50 persen, sedangkan target penerimaan PPN dan PPN BM dikoreksi hingga 45 persen lebih rendah. 
Gambar 1. Target dan Realisasi Penerimaan Pajak Provinsi Kalimantan Selatan s.d. awal Triwulan IV 2020

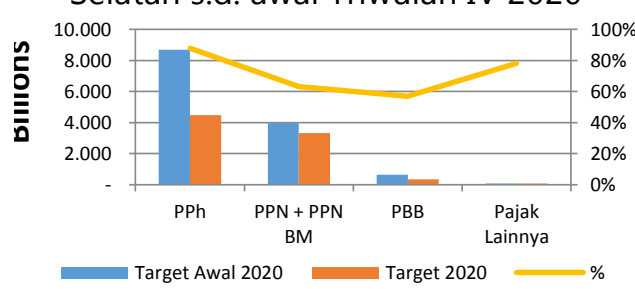

Sumber: Kanwil DJP Kalselteng dan OM SPAN, 2020.

Pendapatan fiskal lebih rendah karena kontraksi ekonomi, sementara pengeluaran fiskal yang digunakan untuk menurunkan dampak krisis akibat pandemi menjadi lebih tinggi (Loayza, 2020). Ibarat dua mata pisau, pemberian insentif pajak memberikan dampak di dua sisi bagi Pemerintah. Di satu sisi berupa tekanan penerimaan, sementara di sisi lainnya Pemerintah juga menghadapi kebutuhan pengeluaran konsumsi berupa dukungan fiskal melalui beragam program bantuan. Meski demikian, dua kondisi tersebut dijalankan secara simultan ditujukan untuk memulihkan kondisi kesehatan dan perekonomian masyarakat.

\section{Program PEN Menahan Pelemahan Tingkat Perekonomian}

Untuk mengukur efektivitas program PEN dalam menahan tingkat perekonomian dari kejatuhan yang lebih dalam, data yang digunakan adalah data series Belanja Konsumsi Pemerintah (G) dan Pengeluaran Konsumsi (C), masing-masing untuk periode 10 (sepuluh) tahun sejak Tahun 2010. Penggunaan data 2 (dua) unsur pembentuk PDRB tersebut untuk mewakili 2 (dua) sisi fungsi stimulus program PEN bagi perekonomian.

\section{$C+I+G+(X-M)=P D R B$}

Dari sisi permintaan (demand side), pengukuran efektivitas program PEN dilakukan atas komponen Konsumsi (C). Sebagaimana diketahui bahwa komponen Konsumsi (C) merupakan salah satu pembentuk angka tingkat pertumbuhan ekonomi (PDRB). Dalam masa krisis pandemi COVID-19, penurunan konsumsi domestik merupakan salah satu dampak pandemi terhadap kondisi ekonomi (Abiad et al., 2020).

Implementasi kebijakan program PEN yang diluncurkan oleh Pemerintah diantaranya diberikan dalam bentuk tunai seperti, bantuan sosial tunai, bantuan subsidi upah, dan juga termasuk insentif kepada Tenaga Kesehatan pusat dan daerah, dimana bantuan dan insentif tersebut merupakan upaya untuk mendongkrak daya beli masyarakat. Oleh karena itu, pengukuran terhadap tingkat Konsumsi (C) diperlukan.

Gambar 2. Prognosis Konsumsi Masyarakat (C) Kalimantan Selatan Dengan Asumsi Tidak Ada

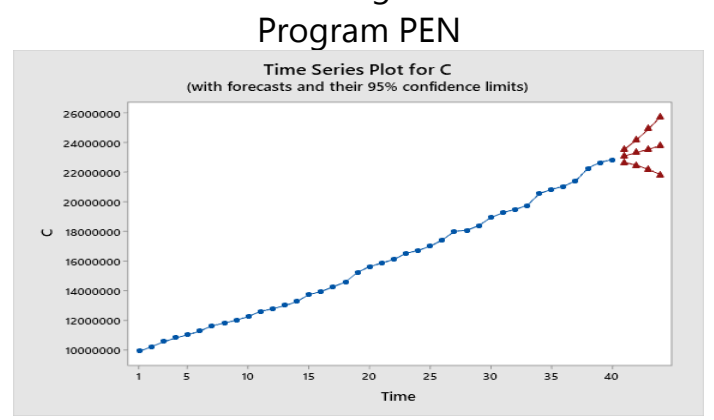

Sumber: BPS Provinsi Kalimantan Selatan (data diolah, 2020) 
Pengukuran nilai prognosis (Gambar 2) di atas menggunakan metode Analisis Trend Eksponensial. Dengan menggunakan pemodelan tersebut dapat diketahui prognosis Pengeluaran Konsumsi Masyarakat (C) dalam kondisi tidak diimplementasikannya program PEN. Data tersebut diperlukan untuk digunakan sebagai data pembanding dengan kondisi Pengeluaran Konsumsi Masyarakat (C) setelah diluncurkannya program PEN. Data yang digunakan adalah data Konsumsi Masyarakat (C) yang merupakan gabungan dari data Pengeluaran Konsumsi Rumah Tangga dan data Pengeluaran Konsumsi Lembaga Non-Profit yang melayani Rumah Tangga (LNPRT) mulai Tahun 2010.

Dari sisi penawaran (supply side), pada saat pendemi ini Belanja Konsumsi Pemerintah menjadi tumpuan utama pengungkit gerak pertumbuhan ekonomi di Indonesia. Berdasarkan Keppres 72 Tahun 2020, struktur alokasi belanja negara dilakukan penyesuaian untuk difokuskan kepada penanganan dampak pandemi COVID-19 sebagaimana dilakukan di negaranagara lain. Banyak negara telah melakukan pemograman ulang anggarannya, mengaktifkan dana cadangan kontigensi, serta mengadopsi anggaran tambahan demi untuk menanggulangi dampak pandemi COVID-19 (Raheem et al., 2020).

Seperti halnya komponen

Konsumsi (C), komponan Belanja Pemerintah (G) juga merupakan bagian pembentuk tingkat PDRB. Berdasarkan hal tersebut, dalam tulisan ini dilakukan pengukuran prognosis Belanja Konsumsi Pemerintah (G) dimaksudkan untuk melihat tingkat PDRB dalam kondisi tanpa diimplementasikannya program PEN (Gambar 3).

Gambar 3. Prognosis Belanja Konsumsi Pemerintah (G) Kalimantan Selatan Dengan Asumsi Tidak Ada Program PEN

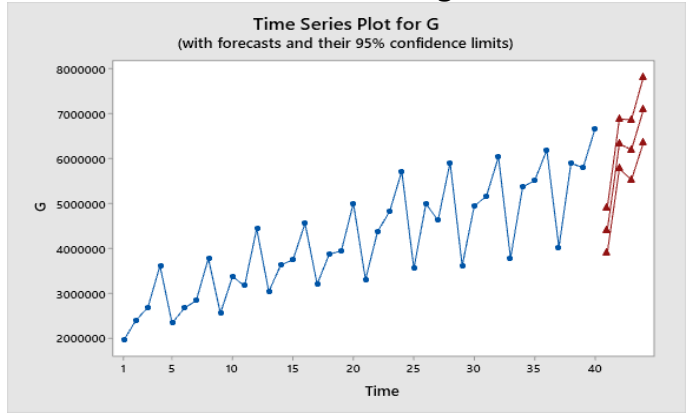

Sumber: BPS Provinsi Kalimantan Selatan (data diolah, 2020)

Dengan menggunakan Model Forecasting Deret Waktu ARIMA, hasil prognosis atas data series realisasi Belanja Konsumsi Pemerintah (G) per Triwulan sejak Tahun 2010 menunjukkan pola musiman. Pola tersebut kemudian digunakan untuk membuat prognosis data Belanja Konsumsi Pemerintah $(G)$, yang kemudian diasumsikan sebagai Belanja Konsumsi Pemerintah (G) dalam kondisi tidak terdapat alokasi untuk program PEN, untuk kemudian dioperasionalkan dalam menghitung PDRB asumsi sebelum diimplementasikannya program PEN.

Data Belanja Konsumsi Pemerintah (G) yang digunakan dalam melakukan prognosis tersebut merupakan data konsolidasian per Triwulan, yang meliputi Belanja Konsumsi Pemerintah (G) dalam APBN yang masuk ke Provinsi Kalimantan Selatan dan yang dialokasikan dalam APBD se-Provinsi Kalimantan Selatan.

Data tingkat Pengeluaran

Konsumsi (C) dan Belanja Konsumsi Pemerintah (G) dioperasionalkan secara 
simultan membentuk tingkat PDRB. Dalam hal ini, tingkat Investasi (I) dan Neraca Perdagangan (X-M) tidak dipengaruhi langsung oleh alokasi program PEN, sehingga menggunakan angka kondisi riil sebagaimana tercatat dalam database BPS Provinsi Kalimantan Selatan. Asumsi tersebut didasarkan pada fakta bahwa karakteristik program PEN yang bersifat tunai untuk mempengaruhi Pengeluaran Konsumsi (C) masyarakat; dan yang non-tunai sebagaipenambah Belanja Konsumsi Pemerintah (G). Bahwa alokasi program PEN tidak ditujukan langsung untuk pembentukan Modal Tetap (I) maupun Neraca Perdagangan (X-M).

Dari sisi permintaan (demand side), program PEN efektif mendongkrak kemampuan/daya beli masyarakat, yang secara langsung akan mempengaruhi tingkat PDRB. Dalam hal ini, bagian dari program PEN yang diberikan dalam bentuk bantuan tunai, baik yang diberikan melalui alokasi

Tabel 1. Perbandingan PDRB Provinsi Kalimantan Selatan, Prognosis dan Eksisting Tahun 2020 (dalam Miliar Rupiah)

\begin{tabular}{|c|c|c|c|c|c|c|}
\hline \multicolumn{7}{|c|}{ Prognosis Tingkat PDRB (Tanpa Program PEN) } \\
\hline \multirow{2}{*}{$\begin{array}{l}\mathrm{Pe} \\
\text { rio } \\
\text { de }\end{array}$} & \multirow{2}{*}{$\begin{array}{c}\text { Proyeksi } \\
\text { (C) jika } \\
\text { tidak ada } \\
\text { Program } \\
\text { PEN } \\
\end{array}$} & \multirow{2}{*}{$\begin{array}{c}\text { Proyeksi } \\
(G) \\
\text { tanpa } \\
\text { Program } \\
\text { PEN }\end{array}$} & \multirow{2}{*}{$\underset{* *}{\mathbf{I}+(\mathbf{X}-\mathbf{M})}$} & \multicolumn{3}{|c|}{$\begin{array}{c}\text { Prognosis Tingkat PDRB } \\
\text { Tanpa Program PEN }\end{array}$} \\
\hline & & & & PDRB & $\mathrm{Q}$ to $\mathrm{Q}$ & $\mathrm{Y}$ on $\mathrm{Y}$ \\
\hline Q1 & $22.663,16$ & $3.893,68$ & $17.358,24$ & $43.547,07$ & $-6,09 \%$ & $4,15 \%$ \\
\hline Q2 & $22.472,49$ & $5.376,84$ & $17.044,27$ & 43.093.60 & $-1,04 \%$ & $-4,28 \%$ \\
\hline Q3 & $22.186,04$ & $5.028,81$ & $17.879,96$ & $4.294,81$ & $74 \%$ & $-6,94 \%$ \\
\hline Q4 & $21.826,82$ & $6.360,14$ & $16.879,92$ & $45.909,08$ & $-0,82 \%$ & $-5,30 \%$ \\
\hline \multicolumn{7}{|c|}{ Tingkat PDRB Eksisting (Setelah Implementasi Program PEN) } \\
\hline \multirow{2}{*}{$\begin{array}{l}\mathrm{Pe} \\
\text { rio } \\
\text { de }\end{array}$} & \multirow{2}{*}{$\begin{array}{l}\text { Kondisi riil } \\
\text { (C) }\end{array}$} & \multirow{2}{*}{$\begin{array}{l}\text { Kondisi } \\
\text { riil (G) }\end{array}$} & \multirow{2}{*}{$I+(X-M)$} & \multicolumn{3}{|c|}{ Tingkat PDRB eksisting } \\
\hline & & & & PDRB & $Q$ to $Q$ & $\mathrm{Y}$ on $\mathrm{Y}$ \\
\hline Q1 & $22.854,38$ & $4.246,66$ & $17.358,24$ & $44.459,28$ & $5,10 \%$ & $4,17 \%$ \\
\hline Q2 & $21.779,72$ & $5.451,61$ & $17.044,27$ & $44.275,59$ & $0,03 \%$ & $-2,61 \%$ \\
\hline Q3 & $22.533,18$ & $5.523,26$ & $17.879,96$ & $45.956,40$ & $3,26 \%$ & $-4,68 \%$ \\
\hline Q4 & $22.834,74$ & $6.725,18$ & $16.879,92$ & $44.459,83$ & $-0,58 \%$ & $-2,94 \%$ \\
\hline
\end{tabular}

Sumber: BPS Provinsi Kalimantan Selatan (data diolah, 2020) dalam anggaran $\mathrm{K} / \mathrm{L}$ maupun yang diberikan melalui tambahan pada Dana Transfer ke Daerah dan Dana Desa akan mempengaruhi langsung tingkat Pengeluaran Konsumsi (C) masyarakat. Sementara itu dari sisi penawaran (supply side), tambahan Belanja Konsumsi Pemerintah (G) sebagai dukungan fiskal dalam beragam jenis klaster program PEN sejak akhir Triwulan I Tahun 2020, secara simultan juga mendorong peningkatan angka PDRB, sebagaimana tercatat resmi oleh Biro Pusat Statistik (Tabel 1).

\section{Program PEN Menahan Laju Kenaikan Tingkat Pengangguran}

Pada bulan Agustus 2020, jumlah angkatan kerja Provinsi Kalimantan Selatan mencapai 2,19 juta orang. Jumlah ini mengalami kenaikan sebesar 51,87 ribu orang dibandingkan keadaan Agustus 2019. Penduduk yang bekerja pada Agustus 2020 adalah sebesar 2,08 juta orang dan mengalami peningkatan 37,49 ribu orang dibandingkan keadaan Agustus 2019.

Berdasarkan hasil evaluasi yang dilakukan oleh Park et al. (2020) menunjukkan bahwa pandemi COVID19 diantaranya berdampak pada tenaga kerja dan pendapatan upah. Di Tiongkok, diperkirakan 5 juta orang kehilangan pekerjaannya dalam 2 bulan pertama di tahun 2020. Tingkat pengangguran di wilayah perkotaan bahkan mencapai 6,2 persen di bulan Februari 2020, meningkat dari 5,3 persen di bulan Januari 2020 dan 5,2 persen di bulan Desember 2019. Serupa itu, hasil evaluasi atas pasar tenaga kerja untuk wilayah Balkan juga menunjukkan bahwa kenaikan angka tingkat pengangguran tahunan mencapai angka tertinggi pada April 
2020, terutama di Albania dan Macedonia Utara (Madźarěviěć-Śujter, 2020). Demikian pula yang terjadi di Indonesia, termasuk Kalimantan Selatan yang dinilai menjadi salah satu wilayah epicentrum penularan COVID-19.

Di Kalimantan Selatan, sejak ditetapkan Pembatasan Sosial Berskala Besar beberapa perusahaan tercatat telah melakukan pengurangan tenaga kerja sehingga berdampak pada lonjakan angka pengangguran dan berkurangnya lapangan kerja bagi penduduk usia kerja.

Data periode Agustus 2020 mencatat bahwa jumlah pengangguran di Provinsi Kalimantan Selatan menjadi 103,65 ribu atau ada penambahan sebesar 14,38 ribu orang (Tabel 2).

Tingkat Pengangguran Terbuka (TPT) adalah persentase jumlah pengangguran terhadap angkatan kerja. TPT diukur sebagai persentase jumlah penganggur/pencari kerja terhadap jumlah angkatan kerja dengan persamaan sebagai berikut:

$$
T P T=\frac{\text { Pencari Kerja }}{\text { Angkatan Kerja }}
$$

Secara definisi, kategori pengangguran terbuka dalam tulisan ini meliputi:

1) Penduduk yang tak mempunyai pekerjaan dan sedang mencari pekerjaan

2) Penduduk yang tak punya pekerjaan dan mempersiapkan usaha

3) Penduduk yang tak punya pekerjaan dan tidak mencari pekerjaan

4) Penduduk yang sudah punya pekerjaan, tetapi belum mulai bekerja.
Tingkat TPT Provinsi Kalimantan Selatan pada bulan Agustus 2020 sebesar 4,74 persen. Indikator ini mengalami kenaikan sebesar 0,56 poin dibandingkan keadaan Agustus 2019. TPT untuk jenjang Sekolah Menengah Atas Kejuruan menempati posisi tertinggi yaitu sebesar 9,01 persen. Sementara itu, TPT terendah terdapat pada jenjang pendidikan SD kebawah yaitu sebesar 2,79 persen. Pada periode ini seluruh kelompok jenjang pendidikan mengalami peningkatan angka TPT, kecuali jenjang pendidikan Sekolah Menengah Atas Kejuruan yang mengalami penurunan selama 3 (tiga) tahun terakhir (Tabel 3).

Tabel 2. Jumlah Penduduk Usia Kerja yang Terdampak COVID-19 di Kalimantan Selatan pada kondisi Agustus 2020

\begin{tabular}{|c|c|}
\hline Pendidikan Tertinggi yang Ditamatkan & Jumlah \\
\hline Pengangguran karena COVID-19 & 27.715 \\
\hline $\begin{array}{l}\text { Bukan Angkatan Kerja (BAK) karena } \\
\text { COVID-19 }\end{array}$ & 11.339 \\
\hline $\begin{array}{l}\text { Sementara Tidak Bekerja Karena } \\
\text { COVID-19 }\end{array}$ & 28.407 \\
\hline $\begin{array}{l}\text { Penduduk Bekerja yang Mengalami } \\
\text { Pengurangan Jam Kerja Karena } \\
\text { COVID-19 }\end{array}$ & 332.585 \\
\hline Total & 400.046 \\
\hline Penduduk Usia Kerja (PUK) & 3.154 .399 \\
\hline Persentase terhadap PUK (\%) & $12,68 \%$ \\
\hline
\end{tabular}

Sumber: BPS Provinsi Kalimantan Selatan (2020)

Definisi Penduduk Usia Kerja adalah penduduk dalam kelompok usia 15 tahun ke atas. Sementara untuk Bukan Angkatan Kerja (BAK) adalah penduduk usia kerja dengan kegiatan bekerja atau punya pekerjaan tetapi sementara tidak bekerja atau pengangguran, atau penduduk usia kerja dengan kegiatan bersekolah, mengurus RT, ataupun melaksanakan kegiatan lainnya. Di masa pandemi, tenaga kerja dalam kelompok muda 
(antara 15 s.d. 24 tahun) merupakan kelompok yang paling terdampak, dan terancam menjadi "lockdown generation" yang akan merasakan beban krisis untuk waktu yang lama (ILO and ADB, 2020). Kelompok tersebut yang memerlukan perhatian lebih dari pemerintah.

Terkait dengan upaya mengatasi lonjakan pengangguran, kebijakan pemerintah Indonesia yang diberikan untuk Kalimantan Selatan berupa dukungan fiskal sektor ketenagakerjaan. Dukungan tersebut berupa bantuan program Kartu Prakerja dengan nilai manfaat masing-masing sebesar 3,55 juta rupiah untuk mengatasi dampak sosial kemasyarakatan akibat pandemi COVID-19. Bantuan tersebut disalurkan kepada 131.811 penerima dengan total nilai manfaat 467,93 miliar rupiah. Dukungan fiskal lainnya berupa bantuan padat karya Kementerian Pertanian sebesar 56 miliar rupiah yang diterimakan kepada 95.426 orang tenaga kerja, padat karya Kementerian Perhubungan sebesar 26,71 miliar rupiah yang diterimakan kepada 739 orang tenaga kerja, serta bantuan padat karya Kementerian PUPR sebesar 165 miliar rupiah.

Efektivitas Program PEN terhadap Tingkat Pengangguran Terbuka tahun 2020 dilakukan dengan metode simulasi berdasarkan data pergerakan TPT dari tahun 2015 (Gambar 4). Simulasi data menggunakan metode forecasting dengan pemodelan ARIMA dan menghasilkan rentang nilai peramalan. Kondisi High atau batas atas rentang nilai peramalan diasumsikan sebagai nilai TPT apabila Pemerintah tidak memberikan bantuan dana PEN kepada masyarakat.
Gambar 4. Prognosis TPT Dengan Asumsi Tidak Adanya Program PEN di Kalimantan

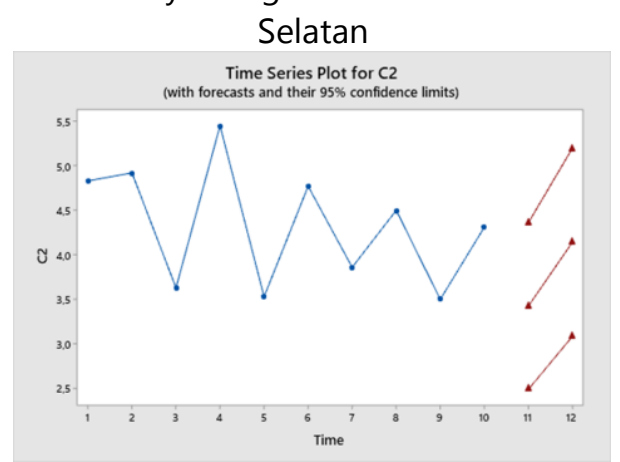

Sumber: BPS Provinsi Kalimantan Selatan (2020)

Angka TPT di Kalimantan Selatan pada masa pandemi periode 2020 diperkirakan akan lebih tinggi 0,56 persen di Bulan Februari dan 0,45 persen di Bulan Agustus pada kondisi tidak ada program PEN, yang dioperasionalkan dengan jumlah angkatan kerja di Kalimantan Selatan mengalami peningkatan YoY dari sebanyak 2,13 juta orang di Agustus 2019 menjadi 2,19 juta orang di Agustus 2020.

Tabel 3. Penduduk Usia Kerja yang Terdampak COVID-19 di Kalimantan Selatan

\begin{tabular}{lcccc} 
Periode & $\begin{array}{c}\text { Jumlah } \\
\text { Angkatan } \\
\text { Kerja }\end{array}$ & $\begin{array}{c}\text { TPT } \\
\text { Simulasi } \\
(\%)\end{array}$ & $\begin{array}{c}\text { TPT } \\
\text { Existing } \\
(\%)\end{array}$ & $\begin{array}{c}\Delta \\
(\%)\end{array}$ \\
\hline $\begin{array}{l}\text { Feb } \\
2019\end{array}$ & 2.248 .595 & - & 3,50 & - \\
Agt & 2.135 .100 & - & 4,18 & - \\
2019 & & & & \\
\hline $\begin{array}{l}\text { Feb } \\
2020\end{array}$ & 2.259 .106 & 4,36 & 3,80 & $-0,56$ \\
Agt & 2.186 .967 & 5,19 & 4,74 & $-0,45$ \\
2020 & & & &
\end{tabular}

Sumber: BPS Provinsi Kalimantan Selatan (2020)

\section{KESIMPULAN DAN SARAN}

Berdasarkan hasil penelitian, implementasi program PEN yang didalamnya juga termasuk rangkaian 
kegiatan penanganan COVID-19 sebagaimana tertuang dalam Peraturan Pemerintah Nomor 23 Tahun 2020, secara efektif menopang tingkat kesejahteraan masyarakat Kalimantan Selatan dari kejatuhan yang lebih dalam.

Program PEN dapat mendorong tingkat PDRB Kalimantan Selatan hingga berada di level -2,61 persen pada Triwulan II, $-4,68$ persen pada Triwulan III, dan -2,94 persen pada Triwulan IV 2020. Kondisi tersebut jauh lebih baik dibandingkan proyeksi kondisi tanpa diimplementasikannya program PEN, yang terpuruk hingga di titik $-4,28$ persen pada Triwulan II, $-6,89$ persen pada Triwulan III, dan $-5,30$ persen pada Triwulan IV 2020.

Program PEN dapat menahan laju pertambahan angka pengangguran terbuka di Kalimantan Selatan sebesar 0,45 persen hingga ke titik 4,74 persen di Agustus 2020, dibandingkan proyeksi kondisi tanpa diimplementasikannya program PEN yaitu di titik yang lebih tinggi yaitu 5,19 persen.

\section{IMPLIKASI}

\section{DAN}

\section{KETERBATASAN}

Penelitian ini terbatas hanya melihat efektivitas program PEN dari ukuran 2 (dua) indikator perekonomian dan kesejahteraan, yaitu tingkat PDRB dan Tingkat Pengangguran Terbuka.

Selain itu, penelitian ini belum mengkaji bagaimana peran tingkat Investasi (I) dan pergerakan Neraca Perdagangan (X-M) terhadap tingkat Pertumbuhan Ekonomi di Kalimantan Selatan, dalam situasi jika program PEN tidak diimplementasikan.

Sangat terbuka peluang bagi penelitian baru, dengan menggali hal- hal yang belum dilakukan di penelitian ini, dengan menggunakan indikator lain yang relevan. Termasuk atas peluang penelitian dengan menggunakan lokus lain, untuk melihat efektivitas program PEN di wilayah lain yang memiliki tantangan yang berbeda, ataupun untuk melihat perbandingan efektivitas program PEN antara daerah epicentrum dan bukan epicentrum penularan COVID-19.

\section{REFERENSI}

Abiad, A., Arao, M., Dagli, S., Ferrarini, B., Noy, I., Osewe, P., Pagaduan, J., Park, D., \& Platias, Reizle. (2020). The Economics Impact of the COVID-19 Outbreak on Developing Asia. ADB Briefs No.128 6 March 2020.

DOI:

http://dx.doi.org/10.22617/BRF200 096

Badan Pusat Statistik Provinsi Kalimantan Selatan. (2020). Provinsi Kalimantan Selatan Dalam Angka 2020. Banjarbaru.

Kanwil Ditjen Perbendaharaan Provinsi Kalimantan Selatan. (2020). Kajian Fiskal Regional Kanwil Ditjen Perbendaharaan Provinsi Kalimantan Selatan Triwulan I 2020. Banjarmasin.

Kanwil Ditjen Perbendaharaan Provinsi Kalimantan Selatan. (2020). Kajian Fiskal Regional Kanwil Ditjen Perbendaharaan Provinsi Kalimantan Selatan Triwulan II 2020. Banjarmasin.

Kanwil Ditjen Perbendaharaan Provinsi Kalimantan Selatan. (2020). Kajian Fiskal Regional Kanwil Ditjen Perbendaharaan Provinsi Kalimantan Selatan Triwulan III 2020. Banjarmasin. 
Kanwil Ditjen Perbendaharaan Provinsi Kalimantan Selatan. (2021). Kajian Fiskal Regional Kanwil Ditjen Perbendaharaan Provinsi Kalimantan Selatan Tahunan 2020. Banjarmasin.

Loayza, N. V. (2020). Costs and Trade Off in the Fights Against the Cost and Trade-Offs in the Fight against COVID-19 Pandemic: A Developing Country Perspective. World Bank Group. Research and Policy Briefs No.35 May 15, 2020.

Loayza, N. V., Sanghi, A., Shaharuddin, N., \& Wuester, L. (2020). Recovery From the Pandemic Crisis: Balancing Short-Term and LongTerm Concern. World Bank Group. Research and Policy Briefs No.38 September 7, 2020.

Madźarěviěć-Śujter, S. (2020). Western Balkan Labor Markets and The COVID-19 Shock. World Bank Group. The Economic and Social Impact of COVID-19: Labor Market

Park, C.Y., Villafuerte, J., Abiad, A., Narayanan, B., Banzon, E. Samson, J., Aftab, A., \& Tayag, M. C. (2020). An Updated Assesment of The Economic Impact of COVID-19. ADB Briefs No.133 May 2020. DOI: http://dx.doi.org/10.22617/BRF200 144-2.

Peraturan Menteri Keuangan Nomor 185/PMK.02/2020 Pengelolaan Anggaran Dalam Rangka Penanganan Pandemi COVID-19 dan/atau Program Pemulihan Ekonomi Nasional. Jakarta.

Peraturan Pemerintah Nomor 23 Tahun 2020 Pelaksanaan Program Pemulihan Ekonomi Nasional Untuk Mendukung Kebijakan Keuangan Negara Untuk Penanganan Pandemi Corona Virus
Disease 2019 (Covid-19) Dan/Atau Untuk Menghadapi Ancaman Yang Membahayakan Perekonomian Nasional Dan/Atau Stabilitas Sistem Keuangan Serta Penyelamatan Ekonomi Nasional. Jakarta.

Peraturan Pemerintah Pengganti Undang-Undang (PERPPU) Nomor 1 Tahun 2020 Kebijakan Keuangan Negara dan Stabilitas Sistem Keuangan untuk Penanganan Pandemi COVID-19 dan/atau Dalam Rangka Menghadapi Ancaman Yang Membahayakan Perekonomian Nasional dan/atau Stabilitas Sistem Keuangan. Jakarta. Peraturan Presiden RI Nomor 72 Tahun 2020 Perubahan Atas Peraturan Presiden Nomor 4 Tahun 2020 tentang Perubahan Postur dan Rincian APBN Tahun Anggaran 2020. Jakarta.

Putri, C. A. (2020). Surabaya, Makassar, dan Kalsel Epicentrum Covid-19.. Diakses tanggal 13 Juni 2021 dari https://www.cnbcindonesia.com/n ews/20200613172745-4165150/surabaya-makassar-dankalsel-epicentrum-covid-19.

Raheem, F., Allen, R., Barroy, H., Gores, L., and Kutzin, J. (2020). COVID-19 Funds in Response to the Pandemic. International Monetary Fund. Fiscal Affairs. Special series on COVID-19 August 26, 2020.

Stephens, A. R. (2017). The Need for Emergency Economic Policy Options to Mitigate the Economic Impacts of Epidemics: Ebola in West Africa and Mers in South Korea. Regional Economies and Policies (REP) 2017(2): 1-11. 